Article

\title{
Performance Assessment of the Semiconductor Industry: Measured by DEA Environmental Assessment
}

\author{
Toshiyuki Sueyoshi ${ }^{1,2}$ and Youngbok Ryu ${ }^{3, * \mathbb{C}}$ \\ 1 Department of Management, New Mexico Institute of Mining \& Technology, 801 Leroy Place, \\ Socorro, NM 87801, USA; Toshiyuki.Sueyoshi@nmt.edu \\ 2 Tokyo Institute of Technology, Tokyo Tech World Research Hub Initiative, School of Environment and \\ Society, 3-6 Shibaura, Minato-ku, Tokyo 108-0023, Japan \\ 3 College of Professional Studies, Northeastern University, 360 Huntington Avenue, Boston, MA 02115, USA \\ * Correspondence: y.ryu@northeastern.edu
}

Received: 14 October 2020; Accepted: 9 November 2020; Published: 17 November 2020

\begin{abstract}
This study measures the unified (i.e., operational and environmental) performance of semiconductor firms in the world by using Data Envelopment Analysis (DEA) environmental assessment. With its promising and expanding electronic applications, many industrial nations have supported the semiconductor industry under their strategic plans, and numerous firms are involved in the global value chain. Drawing on the proposed DEA-based environmental (sustainability) assessment, which uses two disposability criteria (i.e., natural and managerial), this study first compute the unified efficiency scores of semiconductor firms. Then, this study explores how corporate age, business model, and location influence the efficiency scores by employing Tobit regressions and $t$-tests. The empirical implications obtained from this research indicate that overall, the semiconductor firms look for their economic achievements but are not paying enough attention to environmental sustainability. Corporate age and business model are statistically related with their operational performance measures whereas corporate location is related with their environmental ones.
\end{abstract}

Keywords: data envelopment analysis; semiconductor industry; corporate performance

\section{Introduction}

As a brain of electronic products, semiconductors (or integrated circuits) play a major role in the digital economy by performing logical operations, controlling electric current, and digitizing and storing data. With the advent of information and communications technology, particularly semiconductors became essential ingredients for computing, communications, energy, automotive, and industrial applications. Over the past three decades, annual semiconductor sales have increased by almost seven times, from $\$ 73,000$ in 1987 to $\$ 481,090$ in 2018 (in millions of chained 2018 dollars) [1]. Such an explosive growth of the semiconductor industry was enabled by not only increased demand but also improved efficiency stemming from economies of scale and specialization across the value chain from research and designing to manufacturing, assembling, testing, and packaging to distributing [2].

Given that the semiconductor industry significantly contributes to the national economy and competitiveness, many countries and companies have sought to strategically grow the industry by investing aggressively in the semiconductor capital and R\&D (research and development). In the development, there have been two different approaches: (a) Integrated Device Manufacturer (IDM) and (b) fabless-foundry. In the former model, companies (e.g., Intel and Samsung) perform all tasks across the aforementioned value chain by vertical integration. In the latter model, on the other hand, each company is responsible for each value chain process. For instance, Broadcom (in the United States), 
as a fabless, focuses on designing while TSMC (Taiwan Semiconductor Manufacturing Company in Taiwan), as a foundry, specializes in manufacturing. With the globalization and adoption of open innovation, the fabless-foundry model has become popular and, while the IDMs still have the largest revenue share, many IDMs perform all tasks except for manufacturing.

Acknowledging the importance of the semiconductor industry, this study needs to mention that firms have paid attention to corporate profits under the industrial policy of each nation, but not enough consideration on pollution preventions on Greenhouse Gas (GHG) emissions, including carbon dioxide $\left(\mathrm{CO}_{2}\right)$. The pollution prevention increases the image of a good corporate citizen, thereby enhancing the profitability and corporate value in a long run.

The semiconductor industry faces climate change in such a global trend for sustainability enhancement. Despite its minor contribution to reduce the amount of GHG emissions, compared to other industries, the semiconductor industry has proactively addressed the issue, primarily through voluntary agreements. Difficulty in attaining such a low-carbon company is that we do not have a practical method to properly assess both economic development and pollution prevention in a unified framework because the former development has been usually associated with various types of pollutions even in high-tech industries such as semiconductors. Economic development is usually associated with energy consumptions and various pollutions as by-products, if we cannot access green technology.

To partly deal with the methodological difficulty, this research proposes Data Envelopment Analysis (DEA) as a practical method for performance assessment on various firms in the semiconductor industry whose economic activities are characterized by multiple production factors such as $G$ (a vector of desirable outputs) and $X$ (a vector of inputs). The DEA method can assess the performance of many organizations without assuming a functional form among multiple production factors so that the approach is considered as a nonparametric approach. The feature of DEA makes it different from the conventional statistics (e.g., regression) that produce parameter estimates to predict a future estimate. The purpose is not the performance assessment as found in the DEA application.

A problem of the standard DEA to be considered for environmental assessment was that the approach lacked practicality because it did not have any computational capability to handle the existence of $B$ (a vector of undesirable outputs) such as GHG emissions. Unlike the standard DEA, this research used the "DEA environmental assessment" that connects among multiple components $(X, G$, and $B)$ in the assessment. Consequently, the approach can evaluate the unified (operational and environmental) efficiency of many entities, often referred to as "decision-making units" (DMUs, semiconductor firms in this study) by a percentile expression.

Purpose of this study: We apply DEA for assessing the performance of firms in the semiconductor industry, particularly from the perspective of environmental sustainability. Here, it is important to note that while some previous studies have conducted such evaluations, this research is distinct from them from the following four perspectives: (a) First, we measure not only operational but also environmental performance by employing the DEA environmental assessment, which has become a novel approach to the semiconductor industry. (b) Second, we particularly incorporate an energy use (as an input) and the amount of GHG emissions (as an undesirable output) in the proposed performance evaluation where we consider Scope 2 (indirect emissions from the generation of purchased electricity) as well as Scope 1 (direct emissions from semiconductor companies). (c) Third, we consider the dynamic evolution of the semiconductor industry into account in the performance assessment by comparing companies' age and two different business models (IDM vs. fabless-foundry). (d) Finally, we reflect on the geographic aspect of the semiconductor industry (Asian vs. non-Asian location).

At the end of this introduction, we summarize our assumptions to be examined in this study. This research first assumes that semiconductor firms' age, geographic location, and business model may affect their performance. Then, we summarize the following three null hypotheses investigated in this research effort: 
Hypothesis 1. Companies' age is not related to their performance measures (UEN: Unfired Efficiency under Natural Disposability and UEM: Unified Efficiency under Managerial Disposability).

The semiconductor industry has been competitive and dynamic. There have been numerous Merger and Acquisition (M\&A) attempts in the industry. For instance, ATI Technologies, Linear Technology, and Kokusai Electric Corporation were acquired by Advanced Micro Devices in 2006, Analog Devices in 2016, and Applied Materials in 2019, respectively. Furthermore, Advanced Semiconductor Engineering merged with Siliconware Precision Industries in 2016. Surviving in the industry for a long time (and standing in the list of Forbes Global 2000 Companies) means that those companies have competitive advantages over others. Those advantages stem, at least in part, from learning curves over time. The learning effect may affect not only operational but also environmental performance results.

Hypothesis 2. Operation-oriented performance (UEN) of Asian companies is equal to that of non-Asian ones whereas the latter's environment-oriented performance (UEM) is equal to that the former.

Semiconductor manufacturing tends to concentrate in new industrial countries (particularly Asian countries). Integrated device manufacturers (i.e., IDMs), such as Samsung and SK Hynix, and manufacturing-focused companies (foundries) such as TSMC locate in Asia. By the nature of the capital-intensive industry, those companies can take advantage of scale economies through vertical integration and specialization. Thus, the operational performance of Asian countries may outperform non-Asian ones (i.e., European and North American companies). On the other hand, environmental regulations in developing countries tend to be lax when compared to such newly industrial countries. Particularly, European countries have imposed various environmental regulations related to toxic materials, waste, packaging, and labeling in addition to global agreements such as the Kyoto Protocol. In this context, the environmental performances of non-Asian companies outperform those of Asian ones.

Hypothesis 3. Performance measures (UEN and UEM) of fabless companies are equal to those of fabrication ones.

With the development of global value chain, design-focused companies (fabless) emerged as one of the semiconductor business models that outsource semiconductor manufacturing, packaging, and testing to foundries and other companies. Since the semiconductor design is regarded as the most $R \& D$ intensive and value-added process, the operational performance of fabless companies may be higher than that of fabrication (or manufacturing) ones. On the other hand, fabless companies are not involved in the manufacturing process that requires lots of energies (particularly electricity) and entails a huge amount of GHG emissions. Thus, it is expected that the environmental performance of fabless companies may be higher than that of fabrication ones.

The remaining sections are organized as follows: Section 2 conducts a literature survey on DEA and other approaches applied to the semiconductor industry. The section specifies the originality of this study. Section 3 describes the proposed DEA environmental assessment as an approach to evaluate the performance of semiconductor firms in the world. Section 4 summarizes our empirical results obtained in this research. Section 5 concludes this study along with future extensions. The appendix lists abbreviations often used in this study.

\section{Literature Review}

\subsection{Semiconductor Industry}

As semiconductors become embedded in all electronic products and have numerous applications in the emerging fields such as artificial intelligence and the internet of things, the semiconductor-related research activities have increased over time. Given that this study focuses on the technological 
innovation and environmental sustainability aspects of the semiconductor industry and the application of DEA, we briefly present the trend of publications at the intersection of the semiconductor and three different areas (i.e., technological innovation, environmental sustainability, and DEA). By using the Web of Science database, we identified 905, 339, and 39 papers published over the period of 1996-2019 in each area. There have been consistently upward trends in the first two areas (particularly a dramatic increase in the semiconductor-related environmental sustainability area in the 2010s) while the publications in the last area have stagnated, as depicted in Figure 1. In this vein, this study contributes to a paucity of semiconductor-related DEA research. Furthermore, this study proposes a new way to incorporate the technological innovation and environmental sustainability aspects of the semiconductor industry into a DEA research frame.

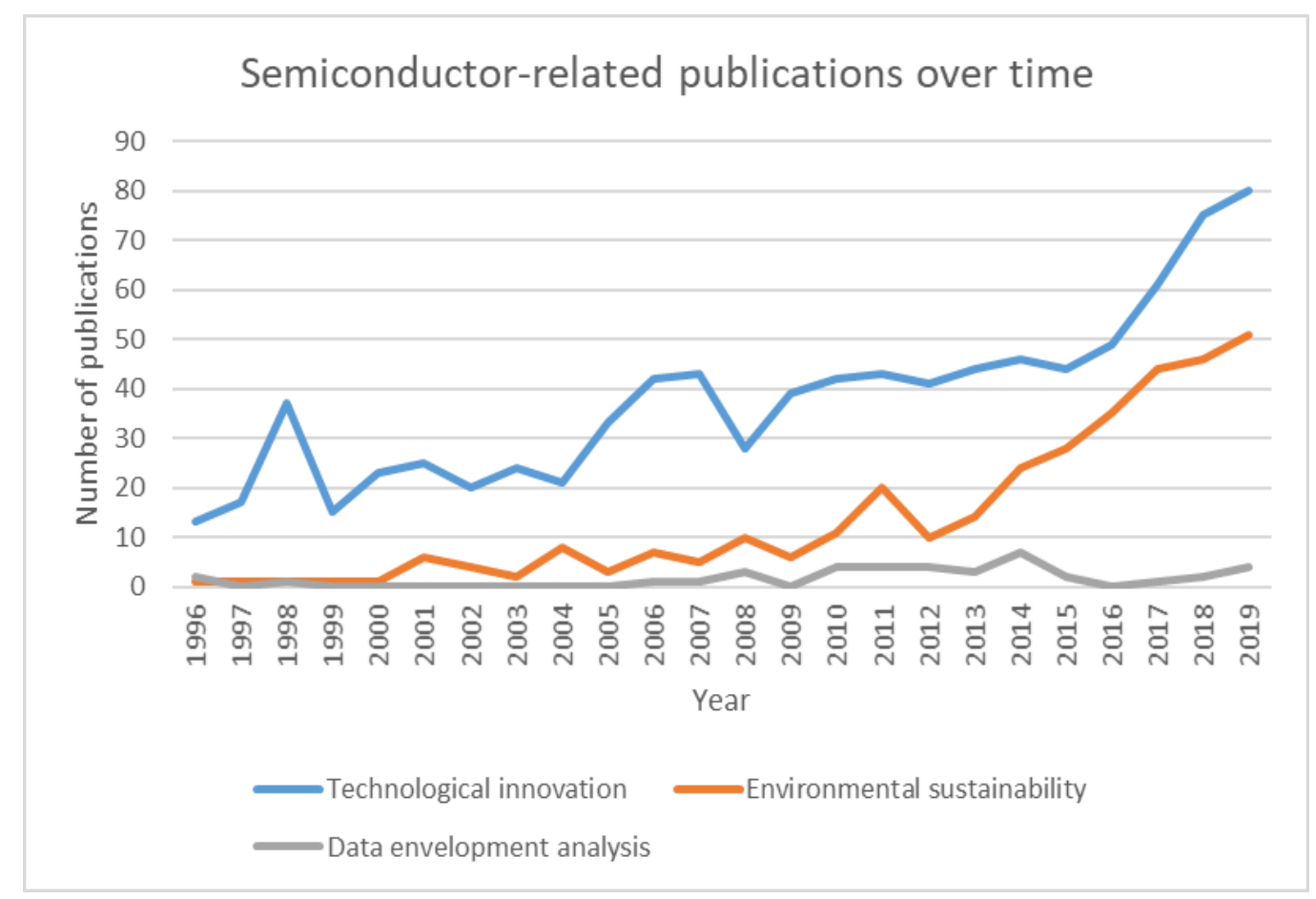

Figure 1. Semiconductor-related publications over time. Note: Keywords used in the Web of Science database are as follows: (semiconductor or "integrated circuit") and (innovation or invention or patent or "intellectual property"), (semiconductor or "integrated circuit") and (sustainability or "greenhouse" or "climate change"), and (semiconductor or "integrated circuit") and ("data envelopment analysis"). While they are not a completely exhaustive list of keywords, we think that it may be sufficient to show their overall trends.

\subsection{Technological Innovation and Environmental Sustainability in the Industry}

Since the semiconductor industry has R\&D-intensive and capital-intensive characteristics, technological innovations created by each firm have played a pivotal role in taking a competitive advantage in the industry. It is evidenced by higher levels of R\&D intensity (i.e., the proportion of $R \& D$ expenditure to total revenue) and patent filings relative to other industries. Particularly, a high propensity to patent in the semiconductor industry has attracted many scholars. Tracing back to the 1990s, the reference [3] explored how technological innovation impacted profitability by looking into the relationship between American semiconductor firms' stocks of R\&D and patents, and Tobin's q. Additionally, the research stressed that because R\&D expenditure (as an input) and patents (as an output) had different characteristics, it was important to include both variables in the empirical model. The reference [4] addressed the patent paradox issue in the semiconductor industry where firms aggressively filed patents while thinking that patents were not the best avenue to recoup their $R \& D$ 
investment. They found some possible explanations such as U.S. propatent public policies and firms' strategic consideration of patents as bargaining chips or vehicles for attracting external investment. More recently, the reference [5] looked into incumbent firms in the semiconductor industry as ones with unique characteristics in which incumbents did not focus on incremental innovations only. To do that, they conducted not only interviews but also patent analyses. Furthermore, the references $[6,7]$ tested alternative variables (e.g., patent quality and average process technology) to the number of patents in linking semiconductor firms' technological innovation to corporate profitability or stock market value.

As the public and private sectors' awareness of the climate change, the sustainability issue emerged in the semiconductor industry. The semiconductor industry has proactively addressed the issue, primarily through voluntary agreements. Under the precompetitive agreements, firms have developed new technologies, shared best practices, and reported their progress to the World Semiconductor Council (WSC) and each country's organizations such as U.S. Semiconductor Industry Association (SIA), Japan Electronic and Information Technology Industries Association (JEITA), European Semiconductor Industry Association (ESIA), Korean Semiconductor Industry Association (KSIA), and Taiwan Semiconductor Industry Association (TSIA). However, their focuses have been placed on perfluorocompounds (PFCs), including hexafluoroethane $\left(\mathrm{C}_{2} \mathrm{~F}_{6}\right)$, octofluoropropane $\left(\mathrm{C}_{3} \mathrm{~F}_{8}\right)$, and tetrafluoromethane $\left(\mathrm{CF}_{4}\right)$, which are primarily used for silicon and dielectric layer etching and chamber cleaning in wafer fabrication equipment. It is because PFCs tend to have higher global warming potential (GWP) and longer atmospheric lifetime than other GHGs do. In this vein, the reference [8] overviewed the PFC emission reduction efforts from technical and internationally collaborative perspectives. The references $[9,10]$ shed light on the role of the voluntary agreements or environmental compliance in Taiwanese and Korean contexts, respectively. The reference [11] measured the sustainability performance of the Taiwanese semiconductor industry by developing a new, balanced scorecard framework based on the fuzzy Delphi and analytic network process methods.

\subsection{DEA Applications to the Semiconductor Industry}

The semiconductor industry is characterized by a highly competitive business environment that often leads to a series of M\&A activities. Table 1 summarizes such previous efforts on studies related to the semiconductor industry. To survive in the industry, it is critical for a firm to benchmark leading competitors and the benchmarking is based on performance evaluation. However, a majority of previous studies were regression-based and tended to look into specific types of performance (e.g., manufacturing, innovation, or financial performance) and place more emphasis on the identification of statistically significant explanatory variables. For instance, the reference [12] examined various variables related to human resource and knowledge systems to explain semiconductor companies' problem-solving performance. The reference [13] looked into technological diversification to shed light on semiconductor companies' innovation performance. The reference [14] explored the effects of work systems (e.g., reward and incentive compensation) on financial and nonfinancial performance. More examples are presented in Table 1.

While regression-based models are useful for determining the relationships between dependent and independent variables, they, as a parametric method, assume a specific relational form between variables and focus on a single dimension of performance, which hinders a holistic view of performance assessment, based on the comparison between outperformers and underperformers, using multiple inputs and multiple outputs. To address these issues, DEA has been proposed and applied to numerous performance measurements in various areas. The semiconductor industry is not an exception.

To date, DEA has been utilized to measure the various types of performance assessment in the semiconductor industry. Table 2 presents the summary of previous DEA studies along with their specific models and their inputs and outputs. Early efforts primarily made on the operating performance were based on the concept of technical or scale efficiency. That is why financial data were mostly used for inputs and outputs and the optimal level of economies of scale was discussed. 
Table 1. Studies related to performance assessment of semiconductor industry.

\begin{tabular}{|c|c|c|c|}
\hline Author(s) & Country & Method & Summary \\
\hline Appleyard et al. [12] & Japan, South Korea, and U.S. & $\begin{array}{l}\text { One-way analysis of variance } \\
\text { (ANOVA) and hierarchical } \\
\text { regression analysis }\end{array}$ & $\begin{array}{l}\text { This study examined the effects of } \\
\text { human resource and knowledge } \\
\text { systems of semiconductor } \\
\text { companies on their } \\
\text { problem-solving performance. }\end{array}$ \\
\hline Chen et al. [13] & Taiwan & Fixed-effect regression model & $\begin{array}{l}\text { This study analyzed how related } \\
\text { and unrelated technological } \\
\text { diversifications affect semiconductor } \\
\text { companies' innovation performance } \\
\text { and corporate growth. }\end{array}$ \\
\hline Tsai [14] & Taiwan & $\begin{array}{l}\text { Correlation and } \\
\text { regression analysis }\end{array}$ & $\begin{array}{l}\text { This study shed light on how high } \\
\text { performance work systems are } \\
\text { associated with organizational } \\
\text { performance in semiconductor } \\
\text { design companies. }\end{array}$ \\
\hline Cheng \& Chang [15] & Taiwan & $\begin{array}{l}\text { Content analysis, cluster } \\
\text { analysis, ANOVA, and } \\
\text { multivariate analysis of } \\
\text { variance (MANOVA) }\end{array}$ & $\begin{array}{l}\text { This study explored how different } \\
\text { types of cognitive strategic groups } \\
\text { and different orientations toward } \\
\text { operation, customer, and product } \\
\text { influence the performance in the } \\
\text { semiconductor industry. }\end{array}$ \\
\hline Cheng et al. [16] & Taiwan & $\begin{array}{l}\text { Fuzzy integral and order weight } \\
\text { average method }\end{array}$ & $\begin{array}{l}\text { This study assessed the financial } \\
\text { performance of the semiconductor } \\
\text { industry taking the interdependence } \\
\text { of financial ratios into account. }\end{array}$ \\
\hline Sattler et al. [17] & World & Paired-comparison method & $\begin{array}{l}\text { This study compared the } \\
\text { manufacturing performance of } \\
\text { semiconductor plants. }\end{array}$ \\
\hline Salomon \& Martin [18] & World & Mixed-effect regression model & $\begin{array}{l}\text { This study looked into the } \\
\text { performance of productive } \\
\text { knowledge deployment in new } \\
\text { semiconductor manufacturing } \\
\text { facilities with a focus on the time it } \\
\text { takes for a company to } \\
\text { operationalize their new facility. }\end{array}$ \\
\hline
\end{tabular}

For instance, the references [19-23] used assets, various kinds of costs, and employees as inputs and revenue and profitability measures (e.g., earnings per share and return on assets) as outputs. Recent studies have started including technological innovation and environmental sustainability-related measures. For another example, the reference [24] analyzed the R\&D efficiencies of Taiwanese semiconductor firms by using R\&D expenditure as one of the inputs and the number of patents as one of the outputs in their dynamic model. The references [25-27] used energy consumption and new technologies as inputs and environmental pollution (e.g., wastewater and solid waste) and GHG emissions as outputs in their cross-efficiency or two-stage additive network model.

Table 2. Data envelopment analysis (DEA) studies applied to semiconductor industry.

\begin{tabular}{|c|c|c|c|c|c|}
\hline Author(s) & Country & Model & Summary & Inputs & Outputs \\
\hline Chen \& Lin [19] & Taiwan & DEA & $\begin{array}{l}\text { This study } \\
\text { assessed the R\&D } \\
\text { performance of } \\
52 \text { Taiwanese } \\
\text { semiconductor firms. }\end{array}$ & $\begin{array}{l}\text { firm age, } \\
\text { paid-in-capital, } \\
\text { R\&D expenditure, } \\
\text { number of R\&D } \\
\text { employees }\end{array}$ & $\begin{array}{l}\text { sales, number } \\
\text { of patents }\end{array}$ \\
\hline Chung et al. [20] & World & $\begin{array}{l}\text { DEA } \\
\text { (Cross-Efficiency) }\end{array}$ & $\begin{array}{l}\text { This study } \\
\text { analyzed global } \\
\text { top } 30 \text { fabless } \\
\text { semiconductor } \\
\text { firms to calculate } \\
\text { and compare their } \\
\text { relative performance. }\end{array}$ & $\begin{array}{l}\text { R\&D Expenses, } \\
\text { fixed assets, } \\
\text { intangible assets, } \\
\text { capital stock, cash, } \\
\text { net working } \\
\text { capital, long-term } \\
\text { investments, } \\
\text { debt ratios }\end{array}$ & $\begin{array}{l}\text { revenue, EBT, } \\
\text { net income } \\
\text { after taxes, EPS, } \\
\text { ROE, ROA, } \\
\text { turnover ratios }\end{array}$ \\
\hline
\end{tabular}


Table 2. Cont.

\begin{tabular}{|c|c|c|c|c|c|}
\hline Author(s) & Country & Model & Summary & Inputs & Outputs \\
\hline Huang et al. [21] & World & $\begin{array}{l}\text { DEA } \\
\text { (MOP/EAM) }\end{array}$ & $\begin{array}{l}\text { This study } \\
\text { computed the } \\
\text { efficiencies of } \\
\text { global top } \\
40 \text { fabless } \\
\text { semiconductor } \\
\text { design firms. }\end{array}$ & $\begin{array}{l}\text { cost of goods sold, } \\
\text { R\&D expenses }\end{array}$ & $\begin{array}{l}\text { total revenue, } \\
\text { ROI, } \\
\text { profitability }\end{array}$ \\
\hline Lu et al. [23] & United States & $\begin{array}{l}\text { 2-stage } \\
\text { approach: DEA } \\
\text { (dynamic) and } \\
\text { panel data } \\
\text { regression }\end{array}$ & $\begin{array}{l}\text { This study } \\
\text { examined how CSR } \\
\text { interplays with the } \\
\text { performance of } \\
89 \text { U.S. } \\
\text { semiconductor firms. }\end{array}$ & $\begin{array}{l}\text { number of } \\
\text { employees, } \\
\text { owner's equity, } \\
\text { liability }\end{array}$ & $\begin{array}{l}\text { gross income, } \\
\text { market value, } \\
\text { excess cost } \\
\text { over equity }\end{array}$ \\
\hline Hatami-Marbini et al. [25] & Middle East & $\begin{array}{l}\text { DEA (cross } \\
\text { efficiency and } \\
\text { fuzzy } \\
\text { data model) }\end{array}$ & $\begin{array}{l}\text { This study } \\
\text { demonstrated the } \\
\text { application of cross } \\
\text { efficiency fuzzy } \\
\text { DEA to selecting } \\
\text { sustainable } \\
\text { suppliers along } \\
\text { with a case } \\
\text { study on } \\
12 \text { semiconductor } \\
\text { suppliers in the } \\
\text { Middle East. }\end{array}$ & $\begin{array}{l}\text { normal inputs: } \\
\text { total cost of } \\
\text { products, energy } \\
\text { consumption, etc.; } \\
\text { desirable inputs: } \\
\text { use of new } \\
\text { technologies, } \\
\text { eco-design } \\
\text { requirements for } \\
\text { energy using } \\
\text { products, } \\
\text { environmental } \\
\text { regulatory } \\
\text { compliance }\end{array}$ & $\begin{array}{l}\text { desirable } \\
\text { outputs: } \\
\text { quality } \\
\text { management } \\
\text { system, } \\
\text { economic } \\
\text { performance, etc.; } \\
\text { undesirable } \\
\text { outputs: } \\
\text { delivery lead } \\
\text { time, } \\
\text { pollution impact }\end{array}$ \\
\hline Lin et al. [26] & Taiwan & $\begin{array}{l}\text { 2-stage additive } \\
\text { network DEA: } \\
\text { business } \\
\text { growth process } \\
\text { and energy } \\
\text { utilization } \\
\text { process; } \\
\text { and AHP }\end{array}$ & $\begin{array}{l}\text { This study } \\
\text { decomposed the } \\
\text { semiconductor } \\
\text { operations into } \\
\text { business growth } \\
\text { stage and energy } \\
\text { utilization stage, } \\
\text { and computed the } \\
\text { sustainability } \\
\text { performance of } 15 \\
\text { Taiwanese }\end{array}$ & $\begin{array}{l}\text { labor, operating } \\
\text { expenses, net } \\
\text { fixed assets }\end{array}$ & $\begin{array}{l}\text { intermediates: } \\
\text { sales, power } \\
\text { consumption, } \\
\text { water } \\
\text { consumptionoutputs } \\
\text { effluent } \\
\text { drainage, } \\
\text { wastes, } \\
\text { GHG gases }\end{array}$ \\
\hline Wu et al. [24] & Taiwan & DEA (MPI) & $\begin{array}{l}\text { This study } \\
\text { measured the R\&D } \\
\text { efficiencies of } 42 \\
\text { Taiwanese } \\
\text { semiconductor } \\
\text { firms and } \\
\text { monitored their } \\
\text { change over time. }\end{array}$ & $\begin{array}{l}\text { total assets, staff } \\
\text { numbers, R\&D } \\
\text { expenditure }\end{array}$ & $\begin{array}{l}\text { ROA, EPS, } \\
\text { number } \\
\text { of patents }\end{array}$ \\
\hline
\end{tabular}

Note: AHP: analytic hierarchy process; CSR: corporate social responsibility; EAM: efficiency achievement measure; EBT: earnings before taxes; EPS: earnings per share; MOP: multiple objectives programming; MPI: Malmquist productivity index; ROA: return on assets, ROE: return on equity; and ROI: return on investment.

Position of this study: In dealing with the undesirable outputs, however, all of the three study groups showed some limitations. For instance, their approaches were simply modeling them as normal inputs or decomposing the overall semiconductor manufacturing process into two subprocesses to treat desirable and undesirable outputs separately in each subprocess. Meanwhile, this study incorporates environmental byproducts into a unified analytic framework by treating them as an undesirable output (not a normal input) and by employing two different concepts of disposability (natural and managerial) without dissecting the semiconductor production process. To explore it further, this study takes the "intermediate approach" for DEA environmental assessment. The rationales concerning why we chose the intermediate approach relative to radial or non-radial approach is that (1) the former is a relatively newer approach than the other two in the manner that we can address the influence of each unified efficiency's component along with the sum of slacks and (b) the former can provide more stable measures by locating its methodological position between the latter two approaches.

Many previous research efforts applied the method to environmental assessment and sustainable development. For example, the reference [28] shed light on a DEA research trend from the 1980s to 
2010s with a focus on its applications. According to their literature review, a great body of studies sought to address the global issue on how to grapple with various challenges in preventing climate change. As a consequence, the number of DEA environmental assessment-based articles has soared, particularly since the 2000s. Their literature survey included extensive peer-reviewed journal articles (i.e., 693 internationally published articles). The follow-up research [29] extended the scope of relevant literature to more than 800 peer-reviewed articles to incorporate the previous conventional DEA applications. Considering the significant contribution of the two previous efforts to DEA applications to environmental assessment and sustainable development, we skipped a detailed description of previous works. Instead, we focused on the methodological aspects of the DEA environmental assessment along with its application on the semiconductor industry.

It is important to describe here that the DEA environmental assessment has three taxonomies in terms of their methodological approaches: "non-radial", "radial", and "intermediate". First, the non-radial approach was initially proposed by the research [30] while the radial approach was proposed by the research [31]. The two articles documented how to unify $G$ with $B$ in a unified structure even if they have opposite vector directions (i.e., maximizing $G$ whereas minimizing $B$ ). The components of $B$ may be considered as "by-products" of $G$. As an alternative to the two approaches, this research employed the intermediate model as our quantitative analysis tool. The first research effort [32] sought to evaluate the sustainability performance of 30 Chinese provinces over the period of 2003 to 2014. The second effort [33] attempted to assess the performance of energy usage and social sustainability in 21 Asian countries over the period of 2008 to 2014. Specifically, the study categorized the Asian nations into four or five groups according to unified efficiency scores computed by the intermediate approach. The third effort [34] was based on the comparison between the intermediate, radial, and non-radial approaches where several unique features of the intermediate approach were discussed relative to the other two approaches. The fourth effort [35] employed the intermediate approach to analyze the province-level performance of Chinese power plants. These studies confirmed the importance (applicability) of the intermediate approach for environmental and sustainability assessment. Finally, the research [36] introduced new disposability concepts and measured Returns to Scale (RTS) and Damages to Scale (DTS) under the two types of disposability, where they imply the elimination of inefficiency. This study serves as an addition to these previous studies on the intermediate approach, focusing upon the performance assessment of the semiconductor industry.

\section{Method}

\subsection{Underlying Concepts}

First of all, nomenclatures used in this section are summarized at the end of this article. In this study, each DMU uses production technology that transforms an input vector $\left(X \in R_{+}^{m}\right)$ with $\mathrm{m}$ components into a desirable output vector $\left(G \in R_{+}^{s}\right)$ with s components and an undesirable output vector $\left(B \in R_{+}^{h}\right)$ with $\mathrm{h}$ components. The axiomatic form of production technology (Te) on a production and pollution possibility set $(P)$ is expressed as follows:

$$
T e=\{P(X): X \text { can produce } G \text { and } B\} \in \mathcal{R}_{+}^{m}
$$

Within the framework of Equation (1), this study uses the "natural" and "managerial" disposability concepts. Axiomatically, the set $(P)$ can be expressed under natural $(N)$ and managerial $(M)$ disposability as follows:

$$
P_{c}^{N}(X)=\left\{(G, B): G \leq \sum_{j=1}^{n} G_{j} \lambda_{j}, B \geq \sum_{j=1}^{n} B_{j} \lambda_{j}, X \geq \sum_{j=1}^{n} X_{j} \lambda_{j} \& \lambda_{j} \geq 0(j=1, \ldots, n)\right\} \&
$$




$$
P_{c}^{M}(X)=\left\{(G, B): G \leq \sum_{j=1}^{n} G_{j} \lambda_{j}, B \geq \sum_{j=1}^{n} B_{j} \lambda_{j}, X \leq \sum_{j=1}^{n} X_{j} \lambda_{j} \& \lambda_{j} \geq 0(j=1, \ldots, n)\right\} .
$$

The above expressions on $P$ incorporate the assumption of constant RTS in Equation (2) and constant DTS in Equation (3) because they do not incorporate the constraint $\left(\sum_{j=1}^{n} \lambda_{j}=1\right)$. The subscript (c) indicates constant RTS or constant DTS. It is also possible to reorganize Equations (2) and (3) by incorporating the constraint into these equations. In that case, the two equations become under variable RTS and variable DTS, so that we need to replace the subscript (c) by the other (v) in Equations (2) and (3). It is true that the restriction on the sum of lambdas is unity may have an infinite number of variations, but all of them except the two possibility (constant and variable) do not have practical implications.

The two Equations (2) and (3) indicate that a difference between the two disposability concepts can be found in the sign of $X$. For natural disposability, DMUs attains two production frontiers by decreasing $X$. In contrast, DMUs reach them by increasing $X$ under managerial disposability. Meanwhile, both natural and managerial disposability share the same conditions $G \leq \sum_{j=1}^{n} G_{j} \lambda_{j} \& B \leq \sum_{j=1}^{n} B_{j} \lambda_{j}$ in these Equations. The underlying implication is that DMUs can reach the two production frontiers by increasing $G$ and/or reducing $B$.

To formulate Equations (2) and (3) by DEA, this study specifies the following three types of data ranges $(R)$ according to the upper and lower bounds of production factors:

$$
\begin{aligned}
R_{i}^{x} & =(m+s+h)^{-1}\left(\max _{j}\left\{x_{i j} \mid j=1, \ldots, n\right\}-\min _{j}\left\{x_{i j} \mid j=1, \ldots, n\right\}\right)^{-1}, \\
R_{r}^{g} & =(m+s+h)^{-1}\left(\max _{j}\left\{g_{r j} \mid j=1, \ldots, n\right\}-\min _{j}\left\{g_{r j} \mid j=1, \ldots, n\right\}\right)^{-1} \& \\
R_{f}^{b} & =(m+s+h)^{-1}\left(\max _{j}\left\{b_{f j} \mid n=1, \ldots, n\right\}-\min _{j}\left\{b_{f j} \mid n=1, \ldots, n\right\}\right)^{-1} .
\end{aligned}
$$

The purpose of the three ranges is that DEA results can avoid an occurrence of zero in dual variables (i.e., multipliers). Such an occurrence implies that corresponding production factors $(X, G$, and $B$ ) are not utilized in the assessment. The occurrence is problematic. Almost all previous DEA studies had this type of difficulty. Therefore, this study incorporated the data ranges into the proposed formulations 3.2.

\subsection{Two Formulations under Constant RTS and DTS}

This study first measures the degree of unified efficiency under natural disposability by the following formulation under constant RTS:

$$
\begin{array}{ll}
\text { Maximize } & \frac{1}{s+h}\left(\sum_{r=1}^{s} \xi_{r}^{g}+\sum_{f=1}^{h} \xi_{f}^{b}\right)+\varepsilon_{s}\left(\sum_{i=1}^{m} R_{i}^{x} d_{i}^{x-}+\sum_{r=1}^{s} R_{r}^{g} d_{r}^{g}+\sum_{f=1}^{h} R_{f}^{b} d_{f}^{b}\right) \\
\text { s.t. } & \sum_{j=1}^{n} x_{i j} \lambda_{j}+d_{i}^{x-}=x_{i k} \quad(i=1, . ., m), \\
& \sum_{j=1}^{n} g_{r j} \lambda_{j}-d_{r}^{g}-\xi_{r}^{g} g_{r k}=g_{r k}(r=1, . ., s) \\
& \sum_{j=1}^{n} b_{f j} \lambda_{j}+d_{f}^{b}+\xi_{f}^{b} b_{f k}=b_{f k}(f=1, . ., h) \\
& 0 \leq \xi_{r}^{g} \leq 1(r=1, . ., s), 0 \leq \xi_{f}^{b} \leq 1(f=1, . ., h), \\
& \lambda_{j} \geq 0(j=1, . ., \mathrm{n}), d_{i}^{x-} \geq 0(i=1, . ., m) \\
& d_{r}^{g} \geq 0(r=1, . ., s) \& d_{f}^{b} \geq 0(f=1, . ., h) .
\end{array}
$$


Here, $\xi_{r}^{g}(r=1, \ldots, s)$ and $\xi_{f}^{b}(f=1, . ., h)$, respectively, stand for subcomponents of an inefficiency score related to desirable and undesirable outputs. Note that the input slack $+d_{i}^{x-}$ in Model (5) indicates that the $k$ th DMU can attain an efficiency frontier by decreasing the amount of inputs under natural disposability. In Model (5), the inefficiency score $(\xi)$ is separated into $\xi_{r}^{g}(r=1, \ldots, s)$ and $\xi_{f}^{b}(f=1, \ldots, h)$, respectively. A computational problem is that they may be more than unity. To avoid the difficulty, the two models incorporate $\xi_{r}^{g} \leq 1(r=1, \ldots, s)$ and $\xi_{f}^{b} \leq 1(f=1, . ., h)$ in the formulation.

Under constant RTS, we determine the level of unified efficiency under natural disposability $\left(U E N(k)_{c}^{I}\right)$ of the $k$ th DMU as follows:

$$
\operatorname{UEN}(k)_{c}^{I}=1-\left[\frac{1}{s+h}\left(\sum_{r=1}^{s} \xi_{r}^{g^{*}}+\sum_{f=1}^{h} \xi_{f}^{b *}\right)+\varepsilon_{s}\left(\sum_{i=1}^{m} R_{i}^{x} d_{i}^{x-*}+\sum_{r=1}^{s} R_{r}^{g} d_{r}^{g^{*}}+\sum_{f=1}^{h} R_{f}^{b} d_{f}^{b *}\right)\right],
$$

where all unknown variables are determined on the optimality of Model (5).

In a similar manner, we measured the degree of unified efficiency under managerial disposability by the following formulation:

$$
\begin{array}{ll}
\text { Maximize } & \frac{1}{s+h}\left(\sum_{r=1}^{s} \xi_{r}^{g}+\sum_{f=1}^{h} \xi_{f}^{b}\right)+\varepsilon_{s}\left(\sum_{i=1}^{m} R_{i}^{x} d_{i}^{x+}+\sum_{r=1}^{s} R_{r}^{g} d_{r}^{g}+\sum_{f=1}^{h} R_{f}^{b} d_{f}^{b}\right) \\
\text { s.t. } & \sum_{j=1}^{n} x_{i j} \lambda_{j}-d_{i}^{x+}=x_{i k} \quad(i=1, . ., m), \\
& \sum_{j=1}^{n} g_{r j} \lambda_{j}-d_{r}^{g}-\xi_{r}^{g} g_{r k}=g_{r k}(r=1, . . s), \\
& \sum_{j=1}^{n} b_{f j} \lambda_{j}+d_{f}^{b}+\xi_{f}^{b} b_{f k}=b_{f k}(f=1, . ., h), \\
& 0 \leq \xi_{r}^{g} \leq 1(r=1, . ., s), 0 \leq \xi_{f}^{b} \leq 1(f=1, . ., h), \\
& \lambda_{j} \geq 0(j=1, . ., \mathrm{n}), d_{i}^{x+} \geq 0(i=1, . ., m), \\
& d_{r}^{g} \geq 0(r=1, . ., s) \& d_{f}^{b} \geq 0(f=1, . ., h) .
\end{array}
$$

Model (7) is formulated under managerial disposability with constant DTS. Model (7) replaces $+d_{i}^{x-}$ by $-d_{i}^{x+}$ in the formulation. No other difference can be found between the two models (5) and (7). The level of unified efficiency $\left(U E N(k)_{c}^{I}\right)$ of the $k$ th DMU under managerial disposability becomes as follows:

$$
\operatorname{UEM}(k)_{c}^{I}=1-\left[\frac{1}{s+h}\left(\sum_{r=1}^{s} \xi_{r}^{g *}+\sum_{f=1}^{h} \xi_{f}^{b *}\right)+\varepsilon_{s}\left(\sum_{i=1}^{m} R_{i}^{x} d_{i}^{x+*}+\sum_{r=1}^{s} R_{r}^{g} d_{r}^{g *}+\sum_{f=1}^{h} R_{f}^{b} d_{f}^{b *}\right)\right]
$$

where all unknown variables are determined on the optimality of Model (7). 


\subsection{Two Formulations under Variable RTS and DTS}

Shifting our description from constant to variable RTS, we reformulate Model (5) as follows:

$$
\begin{array}{ll}
\text { Maximize } & \frac{1}{s+h}\left(\sum_{r=1}^{s} \xi_{r}^{g}+\sum_{f=1}^{h} \xi_{f}^{b}\right)+\varepsilon_{s}\left(\sum_{i=1}^{m} R_{i}^{x} d_{i}^{x-}+\sum_{r=1}^{s} R_{r}^{g} d_{r}^{g}+\sum_{f=1}^{h} R_{f}^{b} d_{f}^{b}\right) \\
\text { s.t. } & \sum_{j=1}^{n} x_{i j} \lambda_{j}+d_{i}^{x-}=x_{i k} \quad(i=1, . ., m), \\
& \sum_{j=1}^{n} g_{r j} \lambda_{j}-d_{r}^{g}-\xi_{r}^{g} g_{r k}=g_{r k}(r=1, . ., s), \\
& \sum_{j=1}^{n} b_{f j} \lambda_{j}+d_{f}^{b}+\xi_{f}^{b} b_{f k}=b_{f k}(f=1, . ., h), \\
& 0 \leq \xi_{r}^{g} \leq 1(r=1, . ., s), 0 \leq \xi_{f}^{b} \leq 1(f=1, . ., h), \\
& \sum_{j=1}^{n} \lambda_{j}=1 \\
& \lambda_{j} \geq 0(j=1, . ., \mathrm{n}), d_{i}^{x-} \geq 0(i=1, . ., m), \\
& d_{r}^{g} \geq 0(r=1, . ., s) \& d_{f}^{b} \geq 0(f=1, . ., h) .
\end{array}
$$

Model (9) additionally incorporates $\sum_{j=1}^{n} \lambda_{j}=1$ into Model (5). The change produces the formulation under variable RTS in Model (9). No other change can be found between them. Under the concept of natural disposability, we measure the level of unified efficiency $\left(\operatorname{UEN}(k)_{v}^{I}\right)$ of the $k$ th DMU by the following equation:

$$
\operatorname{UEN}(k)_{v}^{I}=1-\left[\frac{1}{s+h}\left(\sum_{r=1}^{s} \xi_{r}^{g *}+\sum_{f=1}^{h} \xi_{f}^{b *}\right)+\varepsilon_{s}\left(\sum_{i=1}^{m} R_{i}^{x} d_{i}^{x-*}+\sum_{r=1}^{s} R_{r}^{g} d_{r}^{g *}+\sum_{f=1}^{h} R_{f}^{b} d_{f}^{b *}\right)\right],
$$

where all unknown variables are determined on the optimality of Model (9).

Using Equations (6) and (10), we determine the degree of scale efficiency under natural disposability $(S E N)$ of the $k$ th DMU as follows:

$$
\operatorname{SEN}(k)=U E N(k)_{c}^{I} / U E N(k)_{v}^{I}
$$

In the similar manner, the concept of variable DTS changes Model (9) as follows:

$$
\begin{array}{ll}
\text { Maximize } & \frac{1}{s+h}\left(\sum_{r=1}^{s} \xi_{r}^{g}+\sum_{f=1}^{h} \xi_{f}^{b}\right)+\varepsilon_{s}\left(\sum_{i=1}^{m} R_{i}^{x} d_{i}^{x+}+\sum_{r=1}^{s} R_{r}^{g} d_{r}^{g}+\sum_{f=1}^{h} R_{f}^{b} d_{f}^{b}\right) \\
\text { s.t. } & \sum_{j=1}^{n} x_{i j} \lambda_{j}-d_{i}^{x+}=x_{i k} \quad(i=1, . ., m), \\
& \sum_{j=1}^{n} g_{r j} \lambda_{j}-d_{r}^{g}-\xi_{r}^{g} g_{r k}=g_{r k}(r=1, . ., s), \\
& \sum_{j=1}^{n} b_{f j} \lambda_{j}+d_{f}^{b}+\xi_{f}^{b} b_{f k}=b_{f k}(f=1, . ., h), \\
& 0 \leq \xi_{r}^{g} \leq 1(r=1, . ., s), 0 \leq \xi_{f}^{b} \leq 1(f=1, . ., h), \\
& \sum_{j=1}^{n} \lambda_{j}=1, \\
& \lambda_{j} \geq 0(j=1, . ., \mathrm{n}), d_{i}^{x+} \geq 0(i=1, . ., m), \\
& d_{r}^{g} \geq 0(r=1, . ., s) \& d_{f}^{b} \geq 0(f=1, . ., h) .
\end{array}
$$

Model (12) additionally incorporates $\sum_{j=1}^{n} \geq_{j}=1$ in Model (7). No other change can be found between Models (7) and (12). 
Under the concept of managerial disposability, we measure the level of unified index $\left(U E M(k)_{v}^{I}\right)$ of the $k$ th DMU as follows:

$$
\operatorname{UEM}(k)_{v}^{I}=1-\left[\frac{1}{s+h}\left(\sum_{r=1}^{s} \xi_{r}^{g^{*}}+\sum_{f=1}^{h} \xi_{f}^{b *}\right)+\varepsilon_{s}\left(\sum_{i=1}^{m} R_{i}^{x} d_{i}^{x+*}+\sum_{r=1}^{s} R_{r}^{g} d_{r}^{g^{*}}+\sum_{f=1}^{h} R_{f}^{b} d_{f}^{b *}\right)\right]
$$

where all unknown variables are determined on the optimality of Model (7).

Using Equations (8) and (13), we determine the degree of scale efficiency under managerial disposability (SEM) of the $k$ th DMU as follows:

$$
\operatorname{SEM}(k)=\operatorname{UEM}(k)_{c}^{I} / U E M(k)_{v}^{I}
$$

\subsection{Methodical Strengths and Drawbacks}

Since the reference [34] describes DEA's strengths and drawbacks, this subsection discusses them from the proposed intermediate models and its application to the semiconductor industry. First of all, originated from the "Russell-type of measure," the proposed Models (5)-(14) seek to determine the level of unified efficiency by taking all efficiency components (concerning $X, G$, and $B$ ) into account from the perspective of a methodological tool, which is neither an efficiency score as found in the radial approach nor slacks as found in the non-radial approach. These models are particularly useful in the environmental assessment in that the Russell-type of unified efficiency enables the joint assessment between $G$ and $B$. In this regard, the reference [36] provides a theoretical background to the Russell measure by discussing its mathematical features based on the comparison between the Russell and other (non)radial measures. Since the original Russell measure is characterized by the sum of input efficiency components + the sum of $1 /$ (output efficiency components) in the objective function, which requires nonlinear programming, it was necessary to employ a nonlinear programming approach, such as the second-order cone programming, to calculate the measure [36]. In contrast, the proposed approaches can measure the Russell-type of measure by linear programming. Thus, this study makes it possible to measure the holistic performance of the semiconductor industry. Table 3 summarizes the differences among the aforementioned models in terms of objective functions and constraints.

\begin{tabular}{|c|c|c|c|c|}
\hline Category & Model (5) & Model (7) & Model (9) & Model (12) \\
\hline Measures of Interest & $\begin{array}{l}\text { UEN under } \\
\text { constant RTS }\end{array}$ & $\begin{array}{l}\text { UEM under } \\
\text { constant DTS }\end{array}$ & $\begin{array}{l}\text { UEN under } \\
\text { variable RTS }\end{array}$ & $\begin{array}{l}\text { UEM under } \\
\text { variable DTS }\end{array}$ \\
\hline Objective function & $\begin{array}{l}\text { Inefficiency score } \\
\text { under natural } \\
\text { disposability \& } \\
\text { constant RTS }\end{array}$ & $\begin{array}{l}\text { Inefficiency score } \\
\text { under managerial } \\
\text { disposability \& } \\
\text { constant DTS }\end{array}$ & $\begin{array}{l}\text { Inefficiency score } \\
\text { under natural } \\
\text { disposability \& } \\
\text { variable RTS }\end{array}$ & $\begin{array}{l}\text { Inefficiency score } \\
\text { under natural } \\
\text { disposability \& } \\
\text { variable DTS }\end{array}$ \\
\hline Constraints & Input slack $+d_{i}^{x-}$ & Input surplus $-d_{i}^{x+}$ & $\begin{array}{l}\text { Input slack }+d_{i}^{x-} \& \\
\sum_{j=1}^{n} \lambda_{j}=1\end{array}$ & $\begin{array}{l}\text { Input surplus }-d_{i}^{x+} \\
\& \sum_{j=1}^{n} \lambda_{j}=1\end{array}$ \\
\hline
\end{tabular}

Table 3. Differences among models for DEA environmental assessment.

Second, the proposed approach measures a degree-of-scale efficiency under natural and managerial disposability. The scale efficiency under natural disposability implies how a semiconductor firm efficiently operates its business size under the condition that the operational performance is the first priority. In contrast, that of managerial disposability implies the scale efficiency under the condition that the environmental performance is the first priority.

In contrast to these strengths, the proposed Models (5)-(14) have two drawbacks. First, they do not have any statistical inferences so that they cannot directly link statistical tests. This is a shortcoming of all DEA approaches, including the proposed intermediate assessment. This study discusses how to connect between DEA results and statistical methods (e.g., Tobit regression and statistical tests). 
Finally, we assume that the proposed models produce a unique solution in a computer code. Usually, DEA suffers from an occurrence of multiple solutions such as multiple reference sets, multiple projections, and multiple supporting hyperplanes. The proposed intermediate approach has such a drawback. This study did not direct the research direction because we were interested in the performance assessment of the semiconductor industry, not the theoretical exploration.

\subsection{Applicability}

At the end of this section, it is necessary to mention the applicability of the proposed approach. As discussed in Section 3.4, this study proposes four different models under natural and managerial disposability concepts. They can assess the performance measures of the semiconductor firms from their operational and environmental efforts. This unique feature makes it possible for us to apply the proposed approach to not only the semiconductor industry but also other industries in the world. In particular, the green efforts of firms are essential for their future survival in the global competitive market. As discussed in this study, even the semiconductor industry needs to pay attention to the environmental change so that it can increase its good corporate image. The future applicability (e.g., electric vehicle in a transportation system and digital technology development) of the proposed method needs to include green issues concerning how high-tech companies can reduce the amount of GHG emissions and other various environmental difficulties such as nuclear waste and polluted water treatments.

In addition to the high tech applications, it is possible for us to extend the proposed approach to "medical science". Recently, "coronavirus (COVID-19)" produces many infected people and deaths, both of which can be considered as undesirable outputs in the proposed assessment. After applying our assessment, we can investigate how such a difficulty occurs and circulates all over the world.

\section{Performance Assessment of Semiconductor Industry}

\subsection{Data}

This study focuses on 29 semiconductor companies from the list of Forbes Global 2000 in 2019. Although there were 30 companies on the list, we dropped two (i.e., Longi Green Energy Co. and Marvell Technology Group) due to our data limitation but we added one (Siliconware Precision Industries) since the company belongs to Advanced Semiconductor Engineering (ASE) Technology Holding (on the list) but it is independently operated.

For the analysis in the frame of inputs, desirable outputs, and undesirable outputs, we collect data from four different sources: (a) firm demographics from Forbes, (b) financial data from S\&P Capital IQ, (c) patent data from PatBase, and (d) energy and emissions data from each company's corporate social responsibility (CSR) reports.

There are four inputs: (a) assets, (b) R\&D expenditure, (c) employees, and (d) energy use. Assets are measured by U.S. \$ billion dollars while R\&D expenditure was measured by U.S. \$ million dollars because each company's R\&D intensity (i.e., R\&D expenditure relative to revenue) is about $14 \%$ on average. The number of employees is measured at FTE (full-time equivalent). The amount of energy use is measured by gigawatt hours (GWh). Since each company's CSR (corporate social responsibility) reports use different energy units (e.g., mmBTU: one million British thermal units, and TJ: Tera joule), we unify them to GWh. There are three desirable outputs: sales, profits, and patents. Both sales and profits are measured at U.S.\$ billion dollars. The number of patents is each company's patent applications as of 2018 in two technical areas (semiconductor and GHG reduction), which are represented by Cooperative Patent Classification (CPC) subclasses H01L semiconductor devices and Y02D climate change mitigation technologies in information and communications technology. The GHG is the only undesirable output considered in this study, which is measured in thousand tons of $\mathrm{CO}_{2}$ equivalents. This study considers not only Scope 1 but also Scope 2 into account. 
Table 4 exhibits a data set and descriptive statistics. The data includes not only each company's succinct demographics (e.g., location and corporate age) but also inputs, and desirable and undesirable outputs. Companies are listed in the alphabetical order of continent, country, and their names. There are nine Asian (i.e., Japan, South Korea, and Taiwan), four European (i.e., Germany, The Netherlands, and Switzerland) and 16 North American (i.e., United States) companies. On average, those companies have operated for more than 40 years. As of 2018, individually, they made more than U.S.\$13 billion worth of sales and approximately U.S.\$3 billion worth of profits along with almost 400 patent applications. In their semiconductor design and manufacturing processes, on average, they tend to use about U.S. $\$ 26$ billion worth of assets, U.S. $\$ 2.3$ billion worth of R\&D expenditure, 23,000 employees, and $1500 \mathrm{GWh}$ of energy, which leads to approximately 830,000 tons of $\mathrm{CO}_{2} \mathrm{e}$.

Figure 2 shows the correlations between corporate age and outputs. From Table 4, we have four desirable and undesirable output measures (i.e., the amount of sales, the amount of profits, the number of patent applications and the amount of GHG emissions). We separate Figure 2 into its four components for our visual convenience. Although they are not statistically significant due to the small sample issue, there are positive relationships, suggesting that as companies become older, they tend to produce more outputs (both desirable and undesirable). In this study, the proposed approach does not incorporate a time horizon. It may be possible to think that the corporate age may represent a time horizon in our research framework.

(a) Correlation between firm age and sales

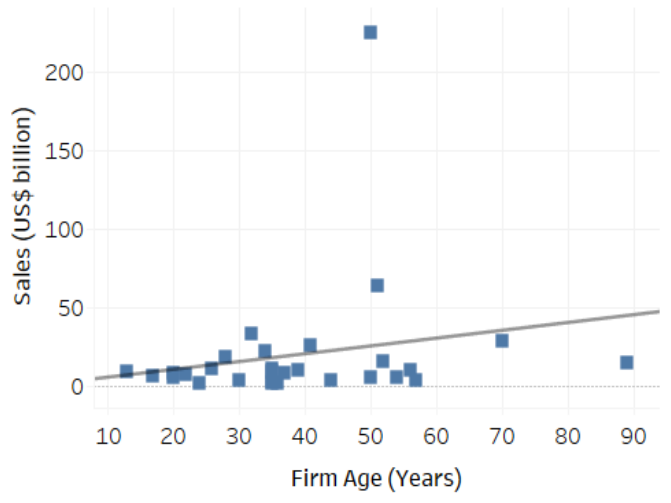

Note: Sales $=0.66+0.50($ Firm Age $)$

R-squared $=0.04$, p-value $=0.30$

(c) Correlation between firm age and the number of patent applications

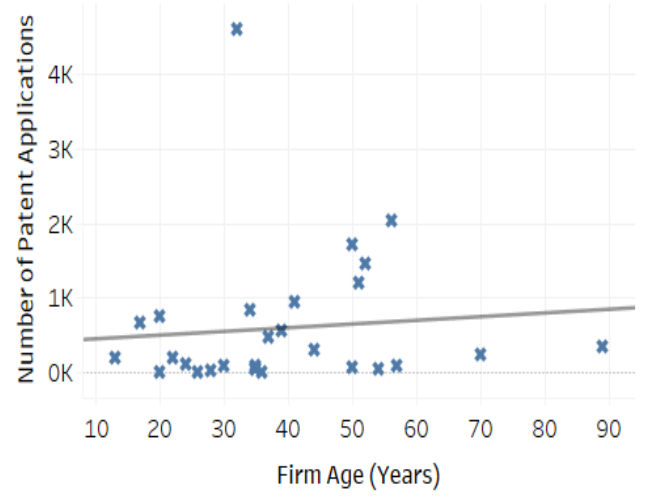

Note: Patents $=402.38+4.94$ (Firm Age)

R-squared $=0.01, \mathrm{p}$-value $=0.65$ (b) Correlation between firm age and profits

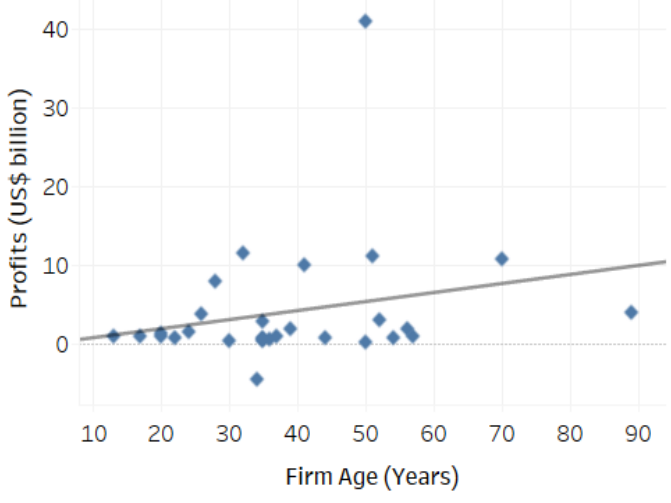

Note: Profits $=-0.49+0.12$ (Firm Age)

R-squared $=0.06, \mathrm{p}$-value $=0.21$

(d) Correlation between firm age and greenhouse gas emissions

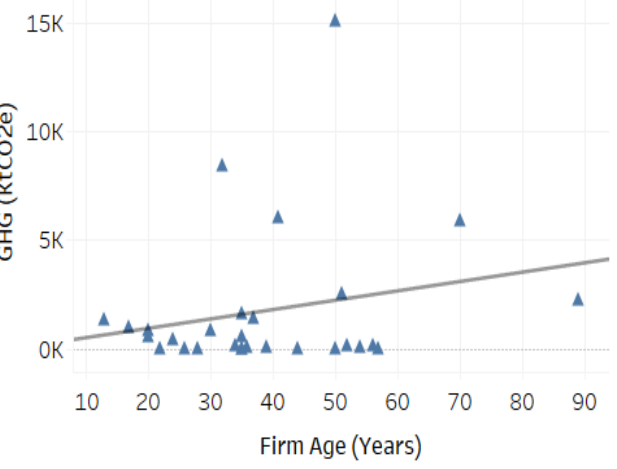

Note: $\mathrm{GHG}=57.18+43.17$ (Firm Age)

R-squared $=0.05$, p-value $=0.26$

Figure 2. Correlations between firm age and outputs: (a) sales; (b) profits; (c) patents and (d) GHG. 
Table 4. Data and descriptive statistics.

\begin{tabular}{|c|c|c|c|c|c|c|c|c|c|c|c|}
\hline \multicolumn{4}{|c|}{ Firm Demographics } & \multicolumn{4}{|c|}{ Inputs } & \multicolumn{3}{|c|}{ Desirable Outputs } & \multirow{2}{*}{$\begin{array}{c}\text { Undesirable Output } \\
\text { GHG }\end{array}$} \\
\hline Company & Country & Continent & $\begin{array}{l}\text { Firm } \\
\text { Age }\end{array}$ & Assets & $\begin{array}{l}R \& D \\
\text { exp. }\end{array}$ & $\begin{array}{l}\text { Total } \\
\text { Empl. }\end{array}$ & $\begin{array}{l}\text { Energy } \\
\text { Use }\end{array}$ & Sales & Profits & Patents & \\
\hline & & & (Yrs) & (US\$ B) & (US\$ M) & (FTE) & (GWh) & (US\$ B) & (\$US B) & (Appl.) & $\left(\mathrm{KtCO}_{2} \mathrm{e}\right)$ \\
\hline Renesas Electronics & Jana & \multirow{9}{*}{ Asia } & 17 & 9.6 & 1170.1 & 19,546 & 5391.67 & 7.1 & 0.83 & 668 & 994 \\
\hline Tokyo Electron & тарап & & 56 & 11.4 & 897.9 & 11,946 & 1128.59 & 10.2 & 1.80 & 2,025 & 152 \\
\hline Samsung Electronics & South & & 50 & 293.2 & $15,833.3$ & 309,630 & $26,028.00$ & 224.6 & 41.00 & 1722 & 15,173 \\
\hline SK Hynix & Korea & & 70 & 46.1 & 1906.0 & 33,190 & $23,327.43$ & 29.3 & 10.70 & 241 & 5914 \\
\hline $\begin{array}{l}\text { ASE Technology } \\
\text { Holding }\end{array}$ & \multirow{5}{*}{ Taiwan } & & 35 & 12.2 & 482.2 & 92,762 & 114.38 & 9.6 & 0.75 & 85 & 1643 \\
\hline MediaTek & & & 22 & 14.2 & 1854.7 & 17,058 & $75.86+$ & 7.7 & 0.68 & 198 & $43+$ \\
\hline Nanya Technology & & & 24 & 5.4 & 157.5 & 3219 & 44.29 & 2.1 & 1.50 & 117 & 448 \\
\hline $\begin{array}{l}\text { Siliconware } \\
\text { Precision Industries }\end{array}$ & & & 35 & 3.8 & 131.8 & 23,000 & 1095.38 & 2.8 & 0.25 & 44 & 581 \\
\hline $\begin{array}{l}\text { Taiwan } \\
\text { Semiconductor }\end{array}$ & & & 32 & 70.3 & 2768.3 & 48,752 & $13,167.00$ & 33.1 & 11.50 & 4592 & 8475 \\
\hline $\begin{array}{l}\text { Infineon } \\
\text { Technologies }\end{array}$ & Germany & \multirow{4}{*}{ Europe } & 20 & 10.1 & 915.3 & 40,098 & 1781.32 & 8.5 & 1.30 & 763 & 915 \\
\hline ASML Holding & & & 35 & 22.9 & 1725.3 & 20,044 & 376.39 & 11.0 & 2.70 & 73 & 33 \\
\hline $\begin{array}{l}\text { NXP } \\
\text { Semiconductors }\end{array}$ & Netherlands & & 13 & 24.1 & 1700.0 & 30,000 & 1450.00 & 9.3 & 0.97 & 201 & 1410 \\
\hline $\begin{array}{l}\text { STMicro } \\
\text { electronics }\end{array}$ & Switzerland & & 37 & 10.1 & 1398.0 & 45,953 & 2439.44 & 8.7 & 0.93 & 479 & 1435 \\
\hline
\end{tabular}


Table 4. Cont.

\begin{tabular}{|c|c|c|c|c|c|c|c|c|c|c|c|}
\hline \multicolumn{4}{|c|}{ Firm Demographics } & \multicolumn{4}{|c|}{ Inputs } & \multicolumn{3}{|c|}{ Desirable Outputs } & \multirow{2}{*}{$\begin{array}{c}\text { Undesirable Output } \\
\text { GHG }\end{array}$} \\
\hline Company & Country & Continent & $\begin{array}{l}\text { Firm } \\
\text { Age }\end{array}$ & Assets & $\begin{array}{l}\text { R\&D } \\
\text { exp. }\end{array}$ & $\begin{array}{l}\text { Total } \\
\text { Empl. }\end{array}$ & $\begin{array}{l}\text { Energy } \\
\text { Use }\end{array}$ & Sales & Profits & Patents & \\
\hline & & & (Yrs) & (US\$ B) & (US\$ M) & (FTE) & (GWh) & (US\$ B) & (\$US B) & (Appl.) & $\left(\mathrm{KtCO}_{2} \mathrm{e}\right)$ \\
\hline $\begin{array}{l}\text { Advanced Micro } \\
\text { Devices }\end{array}$ & \multirow{16}{*}{$\begin{array}{l}\text { United } \\
\text { States }\end{array}$} & \multirow{16}{*}{$\begin{array}{l}\text { North } \\
\text { America }\end{array}$} & 50 & 3.8 & 1434.0 & 10,100 & 121.00 & 6.0 & 0.20 & 63 & 45 \\
\hline Analog Devices & & & 54 & 20.9 & 1165.4 & 15,800 & $231.69+$ & 5.6 & 0.77 & 56 & $112+$ \\
\hline Applied Materials & & & 52 & 19.7 & 2019.0 & 21,000 & 570.92 & 15.5 & 2.90 & 1450 & 173 \\
\hline Broadcom & & & 28 & 54.5 & 3768.0 & 15,000 & $119.28+$ & 18.8 & 7.80 & 22 & $51+$ \\
\hline Intel & & & 51 & 128.6 & $13,543.0$ & 107,400 & 8300.00 & 64.0 & 11.10 & 1205 & 2580 \\
\hline KLA-Tencor & & & 44 & 5.6 & 608.5 & 6550 & $79.36+$ & 3.9 & 0.71 & 306 & $30 \dagger$ \\
\hline Lam Research & & & 39 & 13.7 & 1189.5 & 10,900 & $200.00+$ & 10.3 & 1.90 & 573 & 93 \\
\hline $\begin{array}{l}\text { Maxim Integrated } \\
\text { Products }\end{array}$ & & & 36 & 4.6 & 450.9 & 7149 & 233.79 & 2.4 & 0.44 & 11 & 100 \\
\hline $\begin{array}{l}\text { Microchip } \\
\text { Technology }\end{array}$ & & & 30 & 8.3 & 529.3 & 14,234 & 1024.23 & 4.0 & 0.26 & 90 & 858 \\
\hline Micron Technology & & & 41 & 41.3 & 2141.0 & 36,000 & 7951.22 & 25.9 & 10.00 & 944 & 6100 \\
\hline NVIDIA & & & 26 & 11.5 & 1797.0 & 11,528 & 154.02 & 11.0 & 3.80 & 5 & 59 \\
\hline $\begin{array}{l}\text { ON Semiconductor } \\
\text { Corp. }\end{array}$ & & & 20 & 7.3 & 650.7 & 35,700 & 1344.64 & 5.5 & 0.87 & 10 & 585 \\
\hline Qualcomm & & & 34 & 64.1 & 5619.0 & 35,400 & 691.61 & 22.6 & 2.47 & 838 & 195 \\
\hline Skyworks Solutions & & & 57 & 4.7 & 404.5 & 9400 & $339.04+$ & 3.9 & 0.87 & 85 & $39+$ \\
\hline Texas Instruments & & & 89 & 17.5 & 1559.0 & 29,888 & 3035.52 & 15.3 & 4.00 & 353 & 2268 \\
\hline Xilin $x$ & & & 35 & 5.1 & 639.8 & 4014 & 59.76 & 2.5 & 0.51 & 42 & 26 \\
\hline \multirow{4}{*}{ Descriptive statistics } & Mean & & 43 & 25.7 & 2344.9 & 23,129 & 1528.50 & 13.6 & 3.04 & 378 & 832 \\
\hline & Max & & 89 & 128.6 & $13,543.0$ & 107,400 & 8300.00 & 64.0 & 11.10 & 1450 & 6100 \\
\hline & Min & & 20 & 3.8 & 404.5 & 4014 & 59.76 & 2.4 & 0.20 & 5 & 26 \\
\hline & S.D. & & 16 & 33.1 & 3288.4 & 24,984 & 2682.44 & 15.4 & 3.54 & 478 & 1615 \\
\hline
\end{tabular}

Note: $\dagger=$ extrapolated values based on historical data. All data are based on year 2018, except for Qualcomm's profit that was negative. For the computational purpose, we used 2017 profit data (positive) for Qualcomm. 


\subsection{Efficiency Measures}

Table 5 summarizes the three efficiency measures of 29 firms under natural and managerial disposability concepts. Under natural disposability, we used Models (5) and (9) to measure their UEN measures under CRS, Model (9) to measure their UEN measures under variable RTS and Equation (11) to measure and determine their SEN measures. These results are summarized in the first, second, and third columns under UEN, respectively, in the left-hand side of Table 5.

Table 5. Unified efficiency measures.

\begin{tabular}{|c|c|c|c|c|c|c|}
\hline \multirow{2}{*}{ Company } & \multicolumn{3}{|c|}{ UEN } & \multicolumn{3}{|c|}{ UEM } \\
\hline & Con. RTS & Var. RTS & SEN & Con. DTS & Var. DTS & SEM \\
\hline Advanced Micro Devices & 1.000 & 1.000 & 1.000 & 0.214 & 0.215 & 0.995 \\
\hline Analog Devices & 0.226 & 0.237 & 0.955 & 0.080 & 0.080 & 0.999 \\
\hline Applied Materials & 1.000 & 1.000 & 1.000 & 0.491 & 1.000 & 0.491 \\
\hline ASE Technology Holding & 1.000 & 1.000 & 1.000 & 0.023 & 1.000 & 0.023 \\
\hline ASML Holding & 1.000 & 1.000 & 1.000 & 1.000 & 1.000 & 1.000 \\
\hline Broadcom & 1.000 & 1.000 & 1.000 & 1.000 & 1.000 & 1.000 \\
\hline Infineon Technologies & 0.408 & 0.433 & 0.942 & 0.052 & 0.198 & 0.263 \\
\hline Intel & 0.177 & 1.000 & 0.177 & 0.073 & 1.000 & 0.073 \\
\hline KLA-Tencor & 1.000 & 1.000 & 1.000 & 1.000 & 1.000 & 1.000 \\
\hline Lam Research & 1.000 & 1.000 & 1.000 & 0.473 & 0.512 & 0.923 \\
\hline Maxim Integrated Products & 0.186 & 1.000 & 0.186 & 0.051 & 0.074 & 0.689 \\
\hline MediaTek & 1.000 & 1.000 & 1.000 & 0.617 & 0.617 & 1.000 \\
\hline Microchip Technology & 0.150 & 0.176 & 0.853 & 0.026 & 0.041 & 0.643 \\
\hline Micron Technology & 1.000 & 1.000 & 1.000 & 0.029 & 0.315 & 0.091 \\
\hline Nanya Technology & 1.000 & 1.000 & 1.000 & 0.020 & 0.021 & 0.934 \\
\hline NVIDIA & 1.000 & 1.000 & 1.000 & 0.259 & 0.311 & 0.832 \\
\hline NXP Semiconductors & 0.067 & 0.121 & 0.558 & 0.023 & 0.055 & 0.423 \\
\hline ON Semiconductor Corp. & 0.324 & 0.326 & 0.991 & 0.050 & 0.143 & 0.352 \\
\hline Qualcomm & 0.418 & 1.000 & 0.418 & 0.366 & 1.000 & 0.366 \\
\hline Renesas Electronics & 0.204 & 0.207 & 0.982 & 0.121 & 1.000 & 0.121 \\
\hline Samsung Electronics & 1.000 & 1.000 & 1.000 & 0.037 & 1.000 & 0.037 \\
\hline SK Hynix & 1.000 & 1.000 & 1.000 & 0.086 & 1.000 & 0.086 \\
\hline Skyworks Solutions & 1.000 & 1.000 & 1.000 & 0.211 & 0.229 & 0.924 \\
\hline Siliconware Precision Industries & 1.000 & 1.000 & 1.000 & 0.041 & 0.082 & 0.502 \\
\hline STMicroelectronics & 0.228 & 0.237 & 0.962 & 0.040 & 0.119 & 0.333 \\
\hline Taiwan Semiconductor & 0.797 & 1.000 & 0.797 & 0.040 & 1.000 & 0.040 \\
\hline Texas Instruments & 1.000 & 1.000 & 1.000 & 0.030 & 0.101 & 0.293 \\
\hline Tokyo Electron & 1.000 & 1.000 & 1.000 & 1.000 & 1.000 & 1.000 \\
\hline Xilinx & 0.344 & 1.000 & 0.344 & 0.176 & 1.000 & 0.176 \\
\hline
\end{tabular}

Note: Con. RTS and Var. RTS stand for constant and variabe returns to scale. Con DTS and Var DTS stand for constant and variable damages to scale. SEN and SEM indicate scle efficiency under nartural and managerial disposability.

Table 5 also summarizes their three efficiency measures under the managerial disposability concept. Under managerial disposability, we used Model (7) to measure their UEM measures under constant DTS, Model (12) to measure their UEM measures under variable DTS, and Equation (14) to determine their SEM measures. These results are summarized in the first, second, and third columns under UEM, respectively, in the right-hand side of Table 5.

\subsection{Statistical Analysis}

This study initially examines the differences in the means of production factors between efficient and inefficient firms under UEN and UEM by employing a series of $t$-tests. Table 6 summarizes the results. There are statistically significant differences under UEM but not under UEN, implying that efficient firms tend to use more inputs and produce more desirable and undesirable outputs, particularly in the environmental performance assessment. 
Table 6. Mean test ( $t$-test) between unified efficient and inefficient firm groups.

\begin{tabular}{|c|c|c|c|c|c|c|c|}
\hline & \multirow{3}{*}{$\begin{array}{l}\text { Production } \\
\text { Type Items }\end{array}$} & \multicolumn{3}{|c|}{ UEN (Variable RTS) } & \multicolumn{3}{|c|}{ UEM (Variable DTS) } \\
\hline & & \multicolumn{2}{|c|}{ Mean } & \multirow[b]{2}{*}{$\mathrm{t}$-Statistic } & \multicolumn{2}{|c|}{ Mean } & \multirow[b]{2}{*}{ t-Statistic } \\
\hline & & $\begin{array}{l}\text { Efficient } \\
\text { Companies } \\
(\mathrm{No}=22)\end{array}$ & $\begin{array}{c}\text { Inefficient } \\
\text { Companies } \\
(\mathrm{No}=7)\end{array}$ & & $\begin{array}{l}\text { Efficient } \\
\text { Companies } \\
(\mathrm{No}=13)\end{array}$ & $\begin{array}{l}\text { Inefficient } \\
\text { Companies } \\
(\mathrm{No}=16)\end{array}$ & \\
\hline \multirow{4}{*}{ Inputs } & $\begin{array}{l}\text { Assets } \\
\text { (US\$ B) }\end{array}$ & 38.83 & 12.91 & 1.048 & 57.18 & 12.58 & $2.237^{* *}$ \\
\hline & $\begin{array}{l}\text { R\&D expenditure } \\
\text { (US\$ M) }\end{array}$ & 2769.57 & 1075.53 & 1.048 & 3921.57 & 1092.42 & $2.244^{* *}$ \\
\hline & $\begin{array}{l}\text { Employees } \\
\text { (FTE) }\end{array}$ & $39,269.55$ & $28,761.57$ & 0.414 & $55,787.23$ & $21,252.69$ & $1.653 *$ \\
\hline & $\begin{array}{l}\text { Energy use } \\
\text { (GWh) }\end{array}$ & 3964.22 & 1951.86 & 0.693 & 6104.18 & 1345.09 & $2.025^{* *}$ \\
\hline \multirow{3}{*}{$\begin{array}{l}\text { Desirable } \\
\text { outputs }\end{array}$} & $\begin{array}{l}\text { Sales } \\
\text { (US\$ B) }\end{array}$ & 24.21 & 6.96 & 0.960 & 34.78 & 8.06 & $1.798^{* *}$ \\
\hline & $\begin{array}{l}\text { Profits } \\
\text { (US\$ B) }\end{array}$ & 5.02 & 0.85 & 1.200 & 6.75 & 1.80 & $1.694^{*}$ \\
\hline & $\begin{array}{l}\text { Patents } \\
\text { (Applications) }\end{array}$ & 681.55 & 323.86 & 0.868 & 1020.69 & 249.50 & $2.356^{* *}$ \\
\hline $\begin{array}{l}\text { Undesirable } \\
\text { output }\end{array}$ & $\begin{array}{l}\text { e GHG emissions } \\
(\mathrm{KtCO} 2 \mathrm{e})\end{array}$ & 2010.05 & 901.41 & 0.764 & $2,726.10$ & 943.22 & $1.468^{*}$ \\
\hline
\end{tabular}

Note: No stands for the number of companies. B and $\mathrm{M}$ stand for billion and million. The $t$-test is the mean test to statistically examine whether there is a difference between the two groups. The superscript ${ }^{* *}$ indicates a $5 \%$ significance level and * indicates a 10\% significance level. As shown in the right-hand column, efficient companies outperform the inefficient ones in terms of their magnitudes. This implies that larger firms make more efforts on GHG emission reduction.

To empirically test the hypotheses, we employ Tobit regression models and conducted $t$-tests. Since the efficiency scores have a boundary between 0 and 1 , classical linear regression models can lead to biased results so that we use Tobit regression models that are more appropriate for censored data [37]. With the presence of upper and lower limits on dependent variables, Tobit regression models can generate more unbiased results. In the Tobit model, the observed dependent variables $y_{j}$ for observations $j=1, \ldots, n$ satisfy $y_{j}=\max \left(y_{j}{ }^{*}, 0\right)$ where $y_{j}{ }^{*}$ are latent variables. The latent variables are generated by $y_{j}^{*}=\beta x_{j}+\varepsilon_{j}\left(y_{j}=y_{j}^{*}\right.$ if $y_{j}{ }^{*}>0$ and $y_{j}=0$ otherwise) where $\varepsilon_{j} \sim \mathrm{N}\left(0, \sigma^{2}\right)$ and $\beta$ and $x_{j}$ are unknown parameters and independent variables, respectively. In this study, $y_{j}^{*}$ are latent variables and $y_{j}^{*}$ are efficiency scores (i.e., UEN and UEM).

We use three Tobit models for each efficiency score: models N1-3 for UEN and M1-3 for UEM. The first models include only firms' demographics (N1 under natural disposability and M1 under managerial disposability), the second demographics plus inputs (N2 under natural disposability and M2 under managerial disposability), and the third demographics plus inputs and outputs (N3 under natural disposability and M3 under managerial disposability). Because of multicollinearity, we drop some variables such as assets, sales, and GHG emissions. Controlling input and output variables, we focus upon firms' demographics such as age, location, and business model. The Tobit analysis results are summarized in Table 7. 
Table 7. Summary of Tobit regressions.

\begin{tabular}{|c|c|c|c|c|c|c|}
\hline \multirow{2}{*}{ Variables } & \multicolumn{3}{|c|}{ UEN (Variable RTS) } & \multicolumn{3}{|c|}{ UEM (Variable DTS) } \\
\hline & N1 & N2 & N3 & M1 & M2 & M3 \\
\hline \multicolumn{7}{|l|}{ Demographics: } \\
\hline Firm age & $\begin{array}{c}0.00911^{* *} \\
(2.19)\end{array}$ & $\begin{array}{c}0.0087 \text { * } \\
(2.00)\end{array}$ & $\begin{array}{c}0.0083 * * \\
(2.09)\end{array}$ & $\begin{array}{c}0.0036 \\
(0.71)\end{array}$ & $\begin{array}{l}0.0017 \\
(0.38)\end{array}$ & $\begin{array}{c}0.0006 \\
(0.12)\end{array}$ \\
\hline Location & $\begin{array}{c}0.1715 \\
(1.12)\end{array}$ & $\begin{array}{c}0.2173 \\
(1.20)\end{array}$ & $\begin{array}{c}0.1845 \\
(1.06)\end{array}$ & $\begin{array}{c}0.3288^{*} \\
(1.79)\end{array}$ & $\begin{array}{c}0.3850 * \\
(2.07)\end{array}$ & $\begin{array}{c}0.2818 \\
(1.42)\end{array}$ \\
\hline Business model & $\begin{array}{c}-0.4706^{* *} \\
(-2.69)\end{array}$ & $\begin{array}{c}-0.4500^{* *} \\
(-2.48)\end{array}$ & $\begin{array}{c}-0.4677^{* *} \\
(-2.68)\end{array}$ & $\begin{array}{l}-0.0338 \\
(-0.18)\end{array}$ & $\begin{array}{c}0.0654 \\
(0.35)\end{array}$ & $\begin{array}{c}-0.0693 \\
(-0.34)\end{array}$ \\
\hline \multicolumn{7}{|l|}{ Inputs: } \\
\hline$R \& D$ expenditure & & $\begin{array}{l}0.0000 \\
(1.03)\end{array}$ & $\begin{array}{l}0.0000 \\
(0.26)\end{array}$ & & $\begin{array}{c}0.0002 * * \\
(2.62)\end{array}$ & $\begin{array}{l}0.0001 \\
(1.62)\end{array}$ \\
\hline Employees & & $\begin{array}{c}-0.0000 \\
(-0.19)\end{array}$ & $\begin{array}{c}-0.0000 \\
(-0.58)\end{array}$ & & $\begin{array}{c}-0.0000 \\
(-0.16)\end{array}$ & $\begin{array}{c}0.0000 \\
(0.03)\end{array}$ \\
\hline Energy use & & $\begin{array}{l}-0.0000 \\
(-0.32)\end{array}$ & $\begin{array}{l}-0.0000 \\
(-1.39)\end{array}$ & & $\begin{array}{l}0.0000 \\
(0.03)\end{array}$ & $\begin{array}{l}-0.0000 \\
(-0.09)\end{array}$ \\
\hline \multicolumn{7}{|l|}{ Outputs: } \\
\hline Profits & & & $\begin{array}{l}0.0395 \\
(1.56)\end{array}$ & & & $\begin{array}{l}0.0112 \\
(0.37)\end{array}$ \\
\hline Patents & & & $\begin{array}{l}0.0001 \\
(1.22)\end{array}$ & & & $\begin{array}{c}0.0002 \\
(1.31)\end{array}$ \\
\hline GHG emissions & & & - & & & - \\
\hline Model fit: & & & & & & \\
\hline $\begin{array}{l}\text { R squared } \\
\text { AIC }\end{array}$ & $\begin{array}{c}0.26 \\
39.04\end{array}$ & $\begin{array}{c}0.31 \\
43.16\end{array}$ & $\begin{array}{c}0.44 \\
42.02\end{array}$ & $\begin{array}{c}0.08 \\
48.16\end{array}$ & $\begin{array}{c}0.42 \\
40.19\end{array}$ & $\begin{array}{c}0.48 \\
41.46\end{array}$ \\
\hline BIC & 45.88 & 54.10 & 55.69 & 55.00 & 51.13 & 55.13 \\
\hline
\end{tabular}

Note: ${ }^{* *}$ significant at $5 \%$ and ${ }^{*}$ significant at $10 \%$. Values in the parenthesis are $t$ statistics. Assets, sales, and GHG emissions were dropped in the models because of multicollinearity.

Based on the model fit, we chose the model N1 for UEN and M2 for UEM among all models. Our interpretation follows these two models. According to the analysis results, UEN has statistically significant relationships with firm age and business model while UEM with location and R\&D expenditure. The results partly support the hypotheses summarized in Section 1 in the following manner:

(H1): Firm age is positively related to UEN alone, implying that firms' learning effect resulting from long-standing survival influences their operational performance. The results support half of our first hypothesis. Although the coefficient of firm age in the UEM model is positive, it is not statistically significant. Thus, we cannot verify the relationship between firm age and environmental performance. (H2): Location is positively related to UEM, suggesting that Asian firms are more likely to have better environmental efficiency than non-Asian ones are. The results rebut our second hypothesis. Possible explanations are: (a) While Asian firms use more energies, they tend to emit less GHG, possibly because of Asian firms' higher R\&D expenditure and patent filings in the semiconductor manufacturing and climate change mitigation technologies, when compared to non-Asian firms (the analysis results confirm that R\&D expenditure is positively related to UEM). (b) Voluntary agreements promoted by each country's semiconductor industry association work in Asia. (c) As of 2018, Asian firms' awareness of and attitude toward climate change were sufficiently mature, evidenced by their ambitious corporate social responsibility goals. On the other hand, location does not have a statistically significant relationship with UEN.

(H3): A business model is negatively related to UEN alone, meaning that fabless firms are more likely to have better operational efficiency scores than fabrication firms. The results support the third hypothesis. There is no statistically significant difference in UEM between fabless and fabrication firms. 
This research also performed the $t$-tests for firms' location and business model in UEN and UEM. The $t$-test results in Table 8 reinforce Tobit regression results by validating that Asian firms show better environmental performance than non-Asian ones and fabless firms show better operational performance than fabrication ones.

Table 8. Summary of mean tests.

\begin{tabular}{|c|c|c|c|c|c|c|}
\hline \multirow[b]{3}{*}{ Efficiency } & \multicolumn{3}{|c|}{ Location } & \multicolumn{3}{|c|}{ Business Model } \\
\hline & \multicolumn{2}{|c|}{ Mean } & \multirow[b]{2}{*}{ t-Statistic } & \multicolumn{2}{|c|}{ Mean } & \multirow[b]{2}{*}{ t-Statistic } \\
\hline & $\begin{array}{c}\text { Asian } \\
\text { Companies } \\
(\text { No }=9)\end{array}$ & $\begin{array}{c}\text { Non-Asian } \\
\text { Companies } \\
(\mathrm{No}=20)\end{array}$ & & $\begin{array}{c}\text { Fabless } \\
\text { Companies } \\
(\text { No }=8)\end{array}$ & $\begin{array}{c}\text { Fabrication } \\
\text { Companies } \\
(\mathrm{No}=21)\end{array}$ & \\
\hline UEN (Variable RTS) & 0.91 & 0.78 & 1.020 & 1.00 & 0.75 & $1.907^{* *}$ \\
\hline UEM (Variable DTS) & 0.75 & 0.47 & $1.669 *$ & 0.56 & 0.56 & 0.009 \\
\hline
\end{tabular}

\subsection{Policy Implications}

Besides business interpretations discussed in this section, there are also three policy implications. First, given that the semiconductor industry has strategic implications for countries, particularly for those that desire to lead the fourth industrial revolution characterized by smart technologies such as digital innovation and machine-to-machine communications since these technologies entail the embeddedness of chips, it is critical for countries to grow and sustain the semiconductor industry to be competitive in the future. Particularly, housing companies, which demonstrate superior operational and environmental performance achievements, can domestically contribute to the national competitiveness and sustainability. These countries can readily access high-quality chips that are designed and churned out in an environmentally friendly manner. This may indicate a policy direction for technology development in industrial nations. Second, to grow and sustain operationally outperforming companies, industrial countries need to create a business environment where companies can stand in a long horizon and specialize in some segments of the semiconductor value chain. Particularly, chip design segment is attractive but it requires cutting-edge technologies that can stem from a high level of R\&D expenditure and quality. Thus, countries may want to consider increasing their investments in the semiconductor industry and cultivating a specialized workforce. Finally, to enhance the environmental performance of semiconductor companies, countries need to emphasize the global goals of sustainable development not only through placing environmental regulations but also through supporting private sector-driven voluntary agreements. Moreover, public investment in green technologies is necessary. In terms of knowledge sharing, the success stories of Asian companies' dramatic improvement in the environmental performance need to be disseminated to further the semiconductor industry's green campaigns toward the emission minimization of GHG.

\section{Conclusions and Future Extensions}

There have been publications on the applications of DEA to the semiconductor industry. However, they have focused on the operational performance of semiconductor firms with limited geographical coverages and insufficient considerations of their ages and business models. For instance, many of them used the United States or Taiwan as a study area, measured their efficiencies based on financial data only, and looked into the specific part of the semiconductor value chain without taking corporate age into account. To fill this gap, this study has incorporated not only operational but also environmental performance into the proposed approach by using the DEA environmental assessment's framework, which can address natural and managerial disposability concepts, rather than the standard DEA that can deal with inputs and desirable outputs only. Moreover, this study has expanded the coverage of semiconductor firms' age, location, and business model by exploring the global top 29 firms with 
different establishment dates, which are located in multiple countries (and continents) and engaged in the various stages of the semiconductor value chain.

Our two efficiency measurements under two different disposability schemes (i.e., UEM and UEN) demonstrated that many semiconductor companies ( 22 out of 29 or $76 \%$ of our study sample) were operationally efficient while less than half of them ( 13 out of 29 or $45 \%$ of our study sample) were environmentally efficient. It suggests that there is still room for semiconductor companies to improve their environmental performance. While they have been successful in reducing or replacing PFCs, they still need to reduce overall GHG emission (particularly related to electricity). Another finding is that there are statistically significant differences in production input and output factors between efficient and inefficient companies under UEM but not under UEN. It implies that efficient firms tend to use more inputs and produce more outputs, particularly in the environmental performance assessment. Evidenced by scale efficiency (SEM), larger semiconductor companies tend to be environmentally more efficient. It suggests that frequent M\&A in the semiconductor industry can be a vehicle not only for higher market share but also for more sustainable growth.

Drawing on the statistical analysis results, we also came to the following conclusions. First, corporate age (or how long a firm has survived) may have a signaling effect on the operational performance. Second, corporate location (specifically, whether a firm is located in Asia or not) may matter in the environmental performance. Third, corporate business model (specifically, whether a firm is fabless or specializes in manufacturing) may determine the operating performance. The conclusions reflect that older firms' learning curves and knowledge stock over time play a pivotal role in increasing their operational efficiency in R\&D-intensive industries. Higher value-added processes (i.e., designing chips) also contribute to the operational efficiency of which fabless firms take advantage over manufacturing-oriented firms. Finally, Asian firms' environmental performance outperforms non-Asian ones. With the important role of voluntary agreements across countries, aggressive R\&D investments (and broader innovation activities) exerted by Asian firms may be a primary cause for their higher environmental efficiency.

While this study may offer useful insights into the semiconductor industry, there is some room for improvement. To better reflect the effect of corporate age, firstly, a future study needs to use a longitudinal data set. With panel data covering a sufficient time horizon, we would be able to observe the expansion (or contraction) of efficiency frontiers that represent the productivity change (e.g., Malmquist indices [38,39]). The panel data would also enable us to study the dynamic change of performance, particularly environmental performance, across countries (or continents) in the future. Although Asian firms' environmental efficiency scores outperformed that of counterparts as of 2018, we may hypothesize that the former may be lower than the latter at some point (e.g., in the early 2000s). We are curious about when Asian firms have outperformed non-Asian ones in terms of environmental performance and what the main drivers were. Lastly, the future study may be worth exploring the whole value chain of the semiconductor. While this study focused on the IDM and fabless-foundry business models, the future study may need to incorporate upstream processes such as R\&D (e.g., SEMATECH and Industrial Technology Research Institute) and downstream processes such as assembly/test (e.g., Amkor and ChipPAC) and distribution (e.g., Allied Electronics and Arrow Electronics).

In conclusion, it is hoped that we made a contribution in the semiconductor industry and look forward to seeing future extensions as discussed in this research.

Author Contributions: Conceptualization, T.S.; methodology, T.S.; software, Y.R.; validation, T.S.; formal analysis, T.S.; investigation, Y.R.; resources, Y.R.; data curation, Y.R.; writing-original draft preparation, T.S.; writing-review and editing, T.S. and Y.R.; visualization, Y.R.; supervision, T.S.; project administration, Y.R.; funding acquisition, Y.R. \& T.S. All authors have read and agreed to the published version of the manuscript.

Funding: This research was financially supported by JSPS KAKENHI Grant Number 20KK0106 and Tokyo Institute of Technology in Japan.

Conflicts of Interest: The authors declare no conflict of interest. 


\section{Abbreviations}

$\begin{array}{ll}\text { ASE } & \text { advanced semiconductor engineering } \\ \text { CDS } & \text { constant damages to scale } \\ \text { CPC } & \text { cooperative patent classification } \\ \text { CSR } & \text { corporate social responsibility } \\ \text { DEA } & \text { data envelopment analysis } \\ \text { DMU } & \text { decision-making unit } \\ \text { DTS } & \text { damages to scale } \\ \text { FTE } & \text { full-time equivalent } \\ \text { GHG } & \text { greenhouse gas } \\ \text { GWP } & \text { global warming potential } \\ \text { GWh } & \text { gigawatt hours } \\ \text { IDM } & \text { integrated device manufacturer } \\ \text { RTS } & \text { returns to scale } \\ \text { M\&A } & \text { merger and acquisition } \\ \text { R\&D } & \text { research and development } \\ \text { SEM } & \text { scale efficiency under managerial disposability } \\ \text { SEN } & \text { scale efficiency under natural disposability } \\ \text { UEM } & \text { unified efficiency under managerial disposability } \\ \text { UEN } & \text { unified efficiency under natural disposability } \\ \text { URS } & \text { unrestricted } \\ \text { U.S. } & \text { United States } \\ \text { Nomenclature } & \\ x_{i j} & \text { an observed } i \text { th input of the } j \text { th DMU }(i=1, \ldots, m \text { and } j=1, \ldots, n) \\ g_{r j} & \text { an observed } r \text { th desirable output of the } j \text { th DMU }(r=1, \ldots, s \text { and } j=1, \ldots, n) \\ b_{f j} & \text { an observed } f \text { th undesirable output of the } j \text { th DMU }(f=1, \ldots, h \text { and } j=1, \ldots, n) \\ d_{i}^{x} & \text { an unknown slack variable of the } i \text { th input } \\ d_{r}^{g} & \text { a set of all DMUs } \\ d_{f}^{b} & \\ \lambda & \text { an unknown slack variable of the } f \text { th undesirable output } \\ \varepsilon_{s} & \\ J & \end{array}$

\section{References}

1. Deloitte. Semiconductors-The Next Wave: Opportunities and Winning Strategies for Semiconductor Companies; Deloitte China: 2019. Available online: https://www2.deloitte.com/content/dam/Deloitte/cn/Documents/ technology-media-telecommunications/deloitte-cn-tmt-semiconductors-the-next-wave-en-190422.pdf (accessed on 1 October 2020).

2. Nathan Associates. Beyond Borders: The Global Semiconductor Value Chain; Semiconductor Industry Association: San Jose, CA, USA, 2016.

3. Megna, P.; Klock, M. The impact of intangible capital on Tobin's q in the semiconductor industry. Am. Econ. Rev. 1993, 83, 265-269.

4. Hall, B.H.; Ziedonis, R.H. The patent paradox revisited: An empirical study of patenting in the US semiconductor industry, 1979-1995. RAND J. Econ. 2001, 32, 101-128. [CrossRef]

5. Jiang, L.; Tan, J.; Thursby, M. Incumbent firm invention in emerging fields: Evidence from the semiconductor industry. Strateg. Manag. J. 2011, 32, 55-75. [CrossRef]

6. Cheng, Y.H.; Kuan, F.Y.; Chuang, S.C.; Ken, Y. Profitability decided by patent quality? An empirical study of the US semiconductor industry. Scientometrics 2010, 82, 175-183. [CrossRef]

7. Lou, C.C.; Lee, T.P.; Gong, S.C.; Lin, S.L. Effects of technical innovation on market value of the US semiconductor industry. Technol. Forecast. Soc. Chang. 2010, 77, 1322-1338. [CrossRef]

8. Illuzzi, F.; Thewissen, H. Perfluorocompounds emission reduction by the semiconductor industry. J. Integr. Environ. Sci. 2010, 7, 201-210. [CrossRef] 
9. Lo, S.F. Global warming action of Taiwan's semiconductor/TFT-LCD industries: How does voluntary agreement work in the IT industry? Technol. Soc. 2010, 32, 249-254. [CrossRef]

10. Lee, K.H.; Kim, J.W. Integrating suppliers into green product innovation development: An empirical case study in the semiconductor industry. Bus. Strategy Environ. 2011, 20, 527-538. [CrossRef]

11. Hsu, C.W.; Hu, A.H.; Chiou, C.Y.; Chen, T.C. Using the FDM and ANP to construct a sustainability balanced scorecard for the semiconductor industry. Expert Syst. Appl. 2011, 38, 12891-12899. [CrossRef]

12. Appleyard, M.M.; Brown, C.; Sattler, L. An international investigation of problem-solving performance in the semiconductor industry. J. Prod. Innov. Manag. 2006, 23, 147-167. [CrossRef]

13. Chen, Y.S.; Shih, C.Y.; Chang, C.H. The effects of related and unrelated technological diversification on innovation performance and corporate growth in the Taiwan's semiconductor industry. Scientometrics 2012, 92, 117-134. [CrossRef]

14. Tsai, C.J. High performance work systems and organizational performance: An empirical study of Taiwan's semiconductor design firms. Int. J. Hum. Resour. Manag. 2006, 17, 1512-1530. [CrossRef]

15. Cheng, S.L.; Chang, H.C. Performance implications of cognitive complexity: An empirical study of cognitive strategic groups in semiconductor industry. J. Bus. Res. 2009, 62, 1311-1320. [CrossRef]

16. Cheng, C.H.; Chen, C.T.; Huang, S.F. Combining fuzzy integral with order weight average (OWA) method for evaluating financial performance in the semiconductor industry. Afr. J. Bus. Manag. 2012, 6, 6358-6368.

17. Sattler, L.; Glassey, C.R.; Saeed, B.I. Benchmarking semiconductor manufacturing performance using a pairwise-comparison method. IEEE Trans. Semicond. Manuf. 1997, 10, 317-321. [CrossRef]

18. Salomon, R.; Martin, X. Learning, knowledge transfer, and technology implementation performance: A study of time-to-build in the global semiconductor industry. Manag. Sci. 2008, 54, 1266-1280. [CrossRef]

19. Chen, C.T.; Lin, M.H. Using DEA to evaluate R\&D performance in the integrated semiconductor firms-case study of Taiwan. Int. J. Comput. Internet Manag. 2006, 14, 50-59.

20. Chung, S.H.; Pearn, W.L.; Lee, A.H. Measuring production performance of different product mixes in semiconductor fabrication. Int. J. Ind. Eng. Theory Appl. Pract. 2006, 13, 5-17.

21. Huang, C.Y.; Tzeng, G.H.; Chen, Y.T.; Chen, H. Performance evaluation of leading fabless integrated circuit design houses by using a multiple objective programming based data envelopment analysis approach. Int. J. Innov. Comput. Inf. Control 2012, 8, 5899-5916.

22. Wen, H.C.; Huang, J.H.; Cheng, Y.L. What Japanese semiconductor enterprises can learn from the asset-light business model for sustainable competitive advantage. Asian Bus. Manag. 2012, 11, 615-649. [CrossRef]

23. Lu, W.M.; Wang, W.K.; Lee, H.L. The relationship between corporate social responsibility and corporate performance: Evidence from the US semiconductor industry. Int. J. Prod. Res. 2013, 51, 5683-5695. [CrossRef]

24. Wu, H.Y.; Chen, I.S.; Chen, J.K.; Chien, C.F. The R\&D efficiency of the Taiwanese semiconductor industry. Measurement 2019, 137, 203-213.

25. Hatami-Marbini, A.; Agrell, P.J.; Tavana, M.; Khoshnevis, P. A flexible cross-efficiency fuzzy data envelopment analysis model for sustainable sourcing. J. Clean. Prod. 2017, 142, 2761-2779. [CrossRef]

26. Lin, F.; Lin, S.W.; Lu, W.M. Sustainability assessment of Taiwan's semiconductor industry: A new hybrid model using combined analytic hierarchy process and two-stage additive network data envelopment analysis. Sustainability 2018, 10, 4070. [CrossRef]

27. Mavi, R.K.; Saen, R.F.; Goh, M. Joint analysis of eco-efficiency and eco-innovation with common weights in two-stage network DEA: A big data approach. Technol. Forecast. Soc. Chang. 2019, 144, 553-562. [CrossRef]

28. Sueyoshi, T.; Yuan, Y.; Goto, M. A literature study for DEA applied to energy and environment. Energy Econ. 2017, 62, 104-124. [CrossRef]

29. Sueyoshi, T.; Goto, M. Environmental Assessment on Energy and Sustainability by Data Envelopment Analysis; John Wiley \& Sons: London, UK, 2018; pp. 1-699.

30. Sueyoshi, T.; Goto, M. Data envelopment analysis for environmental assessment: Comparison between public and private ownership in petroleum industry. Eur. J. Oper. Res. 2012, 216, 668-678. [CrossRef]

31. Sueyoshi, T.; Goto, M. Environmental assessment by DEA radial measurement: U.S. coal-fired power plants in ISO (independent system operator) and RTO (regional transmission organization). Energy Econ. 2012, 34, 663-676. [CrossRef]

32. Sueyoshi, T.; Yuan, Y. Social sustainability measured by intermediate approach for DEA environmental assessment: Chinese regional planning for economic development and pollution prevention. Energy Econ. 2017, 66, 154-166. [CrossRef] 
33. Sueyoshi, T.; Yuan, Y. Measuring energy usage and sustainability development in Asian nations by DEA intermediate approach. J. Econ. Struct. 2018, 7, 1-18. [CrossRef]

34. Sueyoshi, T.; Yuan, Y.; Li, A.; Wang, D. Methodological comparison among radial, non-radial and intermediate approaches for DEA environmental assessment. Energy Econ. 2017, 67, 439-453. [CrossRef]

35. Sueyoshi, T.; Li, A.; Gao, Y. Sector sustainability on fossil fuel power plants across Chinese provinces: Methodological comparison among radial, non-radial and intermediate approaches under group heterogeneity. J. Clean. Prod. 2018, 187, 819-829. [CrossRef]

36. Sueyoshi, T.; Goto, M. Intermediate approach for sustainability enhancement and scale related measures in environmental assessment. Eur. J. Oper. Res. 2019, 276, 744-756. [CrossRef]

37. Bi, K.; Huang, P.; Wang, X. Innovation performance and influencing factors of low-carbon technological innovation under the global value chain: A case of Chinese manufacturing industry. Technol. Forecast. Soc. Chang. 2016, 111, 275-284. [CrossRef]

38. Sueyosh, T.; Goto, M. DEA environmental assessment in time horizon: Radial approach for Malmquist index measurement on petroleum companies. Energy Econ. 2015, 51, 329-345. [CrossRef]

39. Sueyosh, T.; Goto, M.; Wang, D. In measurement on frontier shift for sustainability enhancement by Chinese provinces. Energy Econ. 2017, 67, 554-571. [CrossRef]

Publisher's Note: MDPI stays neutral with regard to jurisdictional claims in published maps and institutional affiliations.

(C) 2020 by the authors. Licensee MDPI, Basel, Switzerland. This article is an open access article distributed under the terms and conditions of the Creative Commons Attribution (CC BY) license (http://creativecommons.org/licenses/by/4.0/). 